\title{
Lessons from the Death of a Quango: The British Columbia System of Lay-Councils: 1977-1983
}

\section{(A Personal Perspective)}

\section{JOHN CALDER}

A special thank you is owed to Mr. Don Couch, former executive director of the B.C. Academic Council, for the interviews which made this article possible.

Designers and managers of large complex systems have long grappled with the need to impose central direction without sacrificing sensitivity to outlying parts. British Columbia's College Councils (1978 to 1983) were one province's solution to this perennial dilemma. This article describes, and attempts to account for their creation, particular structure, and demise.

The Academic Council (A.C.), Occupational Training Council (O.T.C.), and Management Advisory Council (M.A.C.) were established under the College and Institutes Act of 1977, and began their work in the following year. In each case the legal instrument of a public (Crown) corporation was used to lend these bodies the quasi-autonomous status felt necessary for them to serve their purpose as buffers between government and the provincial colleges and institutes. The Councils had both advisory and executive power. The principal power of the O.T.C. and A.C., mandated under Part 6 of the Act, was that the Council(s) "shall allocate to the institutions money provided by the government for the programs designated under Section 2(1)(f)". The M.A.C. was to have the power to dispose of all government funds for the colleges and institutes not the responsibility of the other two Councils. In addition, the Councils had other powers to "recommend" "request", or "require" various actions in keeping with the governance needs of the college system.

In July 1983, as part of a large package of provincial legislation, the college Councils were eliminated. While this measure was consistent with the government's drive to "downsize" the public sector, austerity alone is not sufficient to explain the Councils' demise. Most of the 170 quasi-autonomous non-government organizations (quangos) which inhabit the British Columbia polity, including the Universities Council of B.C., survived. In view of the tenacity with which most quangos succeed in clinging to life, it is worthwhile examining the anatomy of the Councils' creation and demise.

The course of the college system from the time of its origin in the early 1960s 
has been, on the whole, a progression towards centralization. In the beginning, decisions were made locally, as befitted the "community" college concept, while more recently, many more decisions have been made by authorities remote from those affected. The first mode is pluralistic and politically sensitive, and sacrifices coordination; the latter is monocentric, directive, inevitably less politically sensitive, but facilitates greater system-wide coordination. Inplicit in this model also is the degree of coercion involved. The centralizing process inevitably implies compelling elements in the structure to do what they otherwise would not.

The Councils had the potential and, indeed, did play a vital role part way on a continuum between these two extremes: making the process of loss of institutional autonomy easier for those affected, while at the same time removing some of the attendant "political heat" from government. The manner in which centralization takes place will depend not only on how events themselves unfold, but on how these events are perceived to do so. This in turn will depend on the predispositions of those who are in power. Tupper and Doern remind us that causes cannot be ascribed wholly either to pragmatism or to ideological preferences (Tupper and Doern, 1981). The remainder of this article will delineate the particular mix of pragmatism, politics, and political thinking behind the fortunes of the college Councils.

\section{DETERMINANTS}

\section{Creation}

B.C.'s community colleges, by definition, had local antecedents. Following the publication of the MacDonald Commission Report in 1962 (MacDonald, 1962), the first two-year colleges were established. They were not governed under their own Act, but, rather, under amendments to the Public Schools Act. These amendments did not circumscribe the roles of community colleges, which "boldly interpreted their major task as responsiveness to community needs" (Dennison, 1979). MacDonald had envisioned autonomous, largely locallysupported institutions offering the first two years of university. Throughout the following fifteen years, the colleges expanded their role to include vocational, career-technical, continuing education, and remedial programs.

From the time of their creation until the tabling of the 1977 College and Institutes Act, there had been constant discussion on how they might better be made to serve provincial as well as community interests. The Winegard Commission toured the province in search of suggestions on how academic education might be improved in non-metropolitan areas, while the Goard Commission did the same for vocational training. The Faris Commission sought recommendations in the area of continuing and community education.

The Act which emerged from this process took eighteen months to draft, and went through, it is said, seventy re-writes (B.C. Legislature, Debates, September 6, 1977). It was the brainchild of the then Minister of Education, Dr. Patrick McGeer, his Deputy Minister, Dr. Walter Hardwick, and others in the Ministry 
Lessons from the Death of a Quango: The British Columbia System of Lay-Councils:

of Education and the Ministry of Labour. Among other highly placed civil servants in Education, there was noticeably less enthusiasm.

Although government statements emphasized the positive contributions of the colleges and institutes, there is no doubt that it believed their efforts were uncoordinated. One major thread of provincial education policy by that time was (and remains) the emphasis on marketable skills. It was hoped that the Councils could act as a vehicle whereby those with a knowledge of what skills were in demand could influence college offerings. There is no doubt, moreover, that the discussions and research - the task forces under the N.D.P. (Province of B.C., Department of Education, 1974), as well as the Commissions - had generated a certain momentum. This momentum, in conjunction with the demonstration effect implied by the existence of interbodies in the American states, lent a certain "do something" urgency to the discussions.

A dictionary definition of "quasi" includes the adjective "seeming". "Quasiautonomous non-government organization", then, is a particularly apt term, for these legal creatures and their advocates can shift deftly from their private/ autonomous incarnation to their public incarnation to suit the needs of the situation. This quality was useful from the outset. Some political thinking at that time favoured devolution of central power. Such a climate meant that the formation of an interbody which appeared to be more autonomous than in fact it might be found favour with centralizers who sought to disguise their aspirations. Such a belief, of course, depended on the extent to which Councils could serve as political camouflage. The 1977 Act's effectiveness in making centralization more palatable was meagre for at least one member (Mr. D.G. Cocke) of the Opposition, who regarded the Academic Council as "the first step on the academic side of the stairway leading to the minister's office" (B.C. Legislature, Debates, September 13, 1977).

As autonomous bodies, the advantage of the Councils in absorbing the responsibility for inter-institutional financial allocation must also have been attractive. Such allocations, if made by the executive arm of the government, would be a politically "no win" dilemma. This was true during the expansionary era, and one might have expected it to be especially so during a contractionary period.

\section{Structure}

There might have been two or even one council. In the event, there were three. Organized labour felt that the province's one-year vocational programs could best enjoy its influence if an Occupational Training Council were formed apart from the Council overseeing academic and career technical programs. Such an arrangement also conformed to the recommendations of the Goard Commission. A third, the Management Advisory Council, to consist of principals (later amended to Chairmen of Boards or their representatives), was formed to oversee capital and equipment programs. This was meant to lend both a countervailing effect 
to the perceived centreward weight of the other two Councils, and to avoid the confusion of splitting capital matters between them.

On several subsequent occasions, the Ministry asked the Councils to review the three-council system. One conclusion was that functions of the M.A.C. could be reallocated without difficulty to the remaining Council or Councils, or to the Ministry (Academic Council, February 14, 1883). The following events were to preclude this option.

\section{Decline and Fall}

In July 1983, the three Councils were eliminated as part of the provincial government's restraint program (Bill 20, College and Institute Amendment Act). At the same time, school trustee appointments to college boards were discontinued. The centralizing trend appeared to be strengthening. The final elimination of the Couricils, however, was not the first manifestation of executive disfavour. In 1982, the main executive function of the Councils, budgetary allocation to the institutions, had been eliminated under the powers given the Minister under the Act. At that time also, the Councils' role in program approval was eliminated. As early as June 1982, the Academic Council, for example, had suffered a budget cut forcing it to remove two research positions from its staff of five. This had vitiated its research capacity, forcing heavier reliance on the Ministry and reducing its autonomy.

The support of the Minister of Education appears to have been crucial to Council fortunes. In 1979, Dr. Patrick McGeer was moved from the Education portfolio. Dr. Hardwick, another architect and advocate of the Council system, also left the Ministry in 1980. Dr. McGeer's place was taken by Mr. Brian Smith, who was in turn replaced in 1982 by William Vander Zalm. In June 1983, Mr. Jack Heinrich took over Education. With the departure of Dr. McGeer, the Councils were to lose a strong advocate. His three successors were indifferent to the Councils at best. Messrs. Smith and Heinrich never met with the Academic Council, though Mr. Vander Zalm did so on one occasion during his brief tenure.

The view of Mr. Heinrich was that the work of the Councils could be accomplished more economically by the Ministry itself (Ministry of Education News Release, July 7, 1983). The Universities Council of B.C., however, under the Minister of Universities, Science, and Communications, Dr. Patrick McGeer, was not eliminated. The Universities Council's own operating budget was equal to that of the other three Councils combined in 1982/83. At least one ally in Cabinet, then, would seem to be a sine qua non.

To what can we attribute these events? Were they:

1. the outcomes of an inevitable drive to centralization of power inherent in all modern states?

2. due to the predilections of certain parties and personalities?

3. due to the absence of any lobby or constituency for the Councils?

4. the result of the real obsolescence of their role in the management of the postsecondary education system? 
The evidence suggests that the first three of these factors were crucial.

Firstly, sweeping attributions of cause to centralizing trends, albeit true, suffer from circularity, and are by themselves unsatisfying. Centralization occurs not sui generis, but as a result of actions taken by people. Such actions are based on their political and ideological perceptions. There is no doubt that in the inner circles of B.C.'s new May 1983 government were people whose approval and advice determined the fate of the province's public bodies. This government felt that increased central power, especially over budget-setting decisions, was necessary to fulfill its mandate for restraint.

As suggested earlier, a quasi-autonomous interbody has greatest appeal to a government concerned about the political impact of its decisions in the affected policy area. The new Social Credit government was more willing to endure the additional inflexibilities of increased centralized decision making and their political consequences, than was the Socred government which had introduced the Council system in 1977.

When the announcement of their elimination came, there were few to lament their passing. The Councils, true to their mandate, had become neither lobbies for the institutions nor unweaned infants of their Ministry. Their intentionallymaintained low profile also meant that few members of the public were even aware of their existence. Bereft of constituency, their passing went almost unprotested in the general outcry over the elimination of many more visible public programs and agencies.

The past contributions of the Councils to the functioning of the postsecondary system, although considerable, had not rendered them obsolete. The governance of the system was, rather, an ongoing problem-solving process which the Councils, through their special advantages as quasi-autonomous non-governmental organizations, might have continued to facilitate. The next section deals with a few examples of the advantages of these quangos, with particular reference to the Academic Council.

\section{Obsolete?}

The achievements and non-achievements of the Councils arose from the special characteristics with which they were endowed. These were their autonomy, their relative political objectivity, their responsiveness to local needs, and their access to expertise.

The autonomy of the Academic Council, for example, along with the availability of sufficient discretionary funds, gave it an agility and heterodoxy which facilitated contracting work with independent entities such as B.C. Research. Although the Ministry also entered into such contracts, the Councils were able to pose research questions - especially those relating to policy and program outcomes - which mainstream educational bureaucracies have been reluctant to face. As a result of such independence, for example, B.C. Research undertook a series of research projects, including studies in degree completion and academic performance of university transfer students. The first of these unprecedented 
studies helped to disclose how many university entrants were surviving, while the latter helped to dispel the widespread myth about the scholastic inferiority of transfer students.

Political objectivity may be a disadvantage as well as an advantage. Agencies ensure their own survival by building up interlocking formal and informal bases of support. The Councils, by their formal mandate, had no clientele. Their decisions sometimes favoured one institution over another and at other times one institution's stand over that of the Ministry, and yet at other times the Ministry's position. Neither institutions nor Ministry, then, had any particular and immediate reason to defend the Councils from attack.

The Councils' responsiveness to local needs was one of their main advantages. The inevitable sensation of remoteness from Victoria felt by many people in community colleges was somewhat allayed by the practice of the Councils holding their meetings on the campuses of the institutions themselves. Of the fiftyseven meetings held over the life of the Academic Council, for example, thirtyseven were held outside of Victoria.

Where a Council was aware sufficiently early of problems between Victoria and an institution, meetings could be scheduled on campus. Several times, differences between institutions and the Ministry were smoothed over by the Academic Council's willingness to visit campuses and hear about problems firsthand. An example was the Academic Council visit to the Fort St. John campus of Northern Lights College to a meeting for discussions when the theatre program was in jeopardy. The danger to playing such a role is that if a Council should too often be perceived as the savior of programs which the Ministry wishes to have dropped, the Council itself may be seen as part of the problem of runaway costs.

Finally, Councils were able to draw on a wealth of expert knowledge and experience. The first chairman of the Academic Council, for example, Dr. Ian McTaggart-Cowan, had been intimately involved with postsecondary education in B.C. for fifty years. Other members were able to bring to the Councils the experience of employers in business and industry.

\section{CONCLUSIONS}

What lessons can students and administrators in the area of postsecondary governance draw from these events? B.C.'s Provincial Councils have been eliminated and are not likely to be resurrected in the near future. The ebb and flow of B.C.'s political tides were probably too powerful to be resisted by the Councils as they were constituted. Parliament is sovereign and no body created by government can live contrary to its will.

The lesson for the designers of future council system is that legislation under which councils operate must not give their main inter-agency rival the power to override their major functions. Given the ineluctable drives of bureaucratic Darwinism, such powers will inevitably be exercised. Only the Legislature should have the power to shorten the distance between councils and their parent ministry. 
Lessons from the Death of a Quango: The British Columbia System of Lay-Councils:

For council members and administrators in provinces where interbodies survive and where political oscillations are more even, there are worthwhile survival tactics. Quasi non-government organizations should exploit to the fullest the camouflage with which they are legally endowed. Where they have benefited institutions, they must be seen by potential beneficiaries to have done so. But where the major functions of a council can be removed by a minister, as in British Columbia, there is clearly little that institutions can do to save it, no matter how much they desire its survival. Its major survival effort, then, would have to consist of tending the hand that feeds it, namely that of its parent ministry. This need not end in total obsequity. Ministries are not monolithic entities. The council senior staff can cultivate contacts in the senior bureaucracy. At the same time, the council chairman must bypass this level, touting to the Minister himself the political advantages of the funds allocation function during cutbacks. The ministry in this case, after all, set the overall amounts available for education. The latitude for independent action is not necessarily circumscribed by such tactics. The key to survival lies in selling different qualities of the quango to different buyers.

\section{REFERENCES}

Academic Council, The Governance of Postsecondary Education in B.C. - A Consideration of the Present State and Future Possibilities, Discussion Paper, February 14, 1982

British Columbia, Legislative Assembly,Debates, September 6, 1977, and September 13,1977

British Columbia Ministry of Education, Report of the Committee on Continuing and Community Education in B.C. (Faris Commission), December 1976

British Columbia, Department of Education, Towards the Learning Community: Report of the Task Force on the Community College in British Columbia, August 1974

B.C. Ministry of Education, News Release, Postsecondary Legislative Changes, August 7, 1983

B.C. Ministry of Education, Report of the Commission on Vocational, Technical, and Trades Training in B.C. (Goard Commission), January 1977

B.C. Ministry of Education, Report of the Commission on University Programs in NonMetropolitan Areas (Wineguard Commission), 1976

Dennison, J.D. Postsecondary Education in B.C.: A Perspective for the 1980s, June 1979

MacDonald, J.B. Higher Education in British Columbia and a Plan for the Future. University of British Columbia, Vancouver, 1962

Tupper, A. \& G.B. Doern. Public Corporations and Public Policy in Canada. The Institute for Research on Public Policy, Montreal, 1981

\section{STATUTES}

College and Institute Act, Chapter 53, 1979

College and Institute Amendment Act, 1980

College and Institute Amendment Act, 1983 (Bill 20) 